\title{
INTRODUCING AESTHETICS INTO STATUS ANALYSIS: THE CASE OF FRENCH CONTEMPORARY POETRY
}

Sébastien Dubois (Neoma BS) et Pierre François (CNRS/Sciences Po-CSO)

\section{INTRODUCTION}

The consecration of artists is a fundamental issue in the study of artistic fields (Bourdieu, 1996; Becker, 1984). What we might call status theory (Podolny, 1993) proposes that consecration (status in Podolny's vocabulary) is constructed through associations between actors, leading the actors to choose partners whose status is comparable to theirs. This theory, widely used in the study of artistic consecration (Giuffre, 1999; Shin et al., 2014; Menger, 2014), remains formal, however. In particular, it hypothesises that when two actors associate, they do so on the basis of their relative position in their respective areas of reference. The aim of this article is to complete this hypothesis, whose relevance to the world of contemporary poetry we have discussed elsewhere (Dubois and François, 2013), by showing how aesthetic affinities can contribute to pairing choices (between a publisher and a poet, in particular), and how these aesthetic affinities can play a determining role in unequal artistic consecration.

Poetry is a particularly suitable area for this theoretical perspective. Commercial logics are indeed rarely present, and commercial value is a result of the literary recognition a poet may acquire. Poetry is a relatively independent space in Bourdieu's sense (1996). The different artistic evaluations (literary awards, critical acclaim, academic recognition and anthologies) all feature the same names: it is thus possible to work with a clear, established hierarchy, from which the dominant figures of French twentieth century poetry emerge who, doubtless, will maintain their reputation with the passage of time, in what Schmutz calls retrospective consecration (Schmutz, 2005).

We have organised the article as follows. We begin by discussing status theory, including the nature of relations between actors. Next, we present our data and methods. The third section shows that the world of contemporary poetry is organised around aesthetic affinities and social solidarities, divided between three key publishers. The fourth section shows how this aesthetic segmentation of the world of contemporary poetry carries over to differing degrees of 
consecration. The final section concludes with the contribution of status theory and a detailed analysis of art history.

\section{STATUS AND AESTHETICS IN CONSECRATION TRAJECTORIES}

Status theory is based on two principal hypotheses (Menger, 2014). The first proposes that the differences in consecration that we may observe retrospectively are the result of a process of progressive amplification of differences that are initially insignificant. The second hypothesis proposes that this enlargement of gaps that were originally tiny is based above all on a logic of selective matching (Podolny, 1993): actors associate with others with the same status as themselves, whatever their field, so that each one's consecration enhances that of the other. In this way, the gaps from those who are inferior grow larger. This explanation can be criticised for its formal nature: whatever the qualities of artistic production, the only thing that counts is the difference in recognition and the actors' propensity to associate with partners who enjoy an equivalent or greater level of prestige.

However, associations between actors can be based on factors other than their relative status. In artistic worlds in particular, they can be based on aesthetic affinities: film producers do not work with a particular director only because they enjoy equivalents levels of prestige in their respective fields; they do so also because the director's aesthetic tastes correspond to the producer's project (Mary, 2006). In the case of the world of literature, as in many other artistic fields, aesthetic identity plays a key role. Publishers have long sought to develop an aesthetic, intellectual and commercial identity; this is the very idea of the literary collection, which has been the publisher's principle commercial tool since the second half of the nineteenth century (Mollier, 1988). The question is particularly important in artistic worlds such as poetry, in which literary value is at the heart of the assessment of work, and is the basis of its commercial value. In these circumstances, whilst actors certainly tend to associate with others according to their respective level of prestige, status theory does not explain why a celebrated poet will work with a particular respected publisher rather than with another publisher with a similar reputation. Apart from the formal logic of status, we have to look at the contents of the relations between partners, in this case between poet and publisher, and more precisely the aesthetic identity on which this association is based. 
This perspective, in the case of poetry, leads us to study two principal factors in detail. The first is the fact that for poets, publishers are markers not only of status but also of aesthetics: by working with this publisher rather than another, the poet positions him/herself in a specific area of a heterogeneous, conflictual aesthetic space. We will describe the three mechanisms by which publishers construct a particular aesthetic identity: this identity is obviously based on the selection they make among the work they receive, but also on the fact that groups of poets form around them, which operate as spaces for the socialisation of new poets, and later as spaces for the sociability of more established poets. These social mechanisms contribute to perpetuate the aesthetic segmentation of the poetry world. The second point raises the question of how this aesthetic segmentation takes on a vertical dimension: how do these aesthetic affinities influence the shared, stable hierarchies, which, as we have shown, structure the world of contemporary poetry? We will focus on the two main mechanisms that explain how these aesthetic affinities influence consecration: the use of publishers by those who influence reputation as a means of evaluating poets, the perpetuation within the consecration bodies of the solidarities operating in the poetry world.

\section{Data \& Methods}

We base our study on a bio-bibliographical database of 150 poets born since 1920, and therefore who began their career after the Second World War. We began with a list of 722 poets compiled from several institutional, critical and anthological sources. We selected the 150 best-known (we detailed our method of developing this database in Dubois and François (2013)). We divided this list into three groups with differing degrees of consecration: by combining multiple correspondence analysis and cluster analysis, we show that the different elements of consecration (literary awards, critical recognition, and academic recognition) converge to form a generally consistent hierarchy in the world of contemporary poetry. We assigned each poet to one of the three clusters (dominant, median or dominated) that emerged from the hierarchical list. We completed our database by searching systematically through all the $\mathrm{PhD}$ theses dealing with contemporary poetry presented over the last thirty years (1985-2015).

Since this research is attempting to uncover the details of relations between poets and publishers, we have to investigate the aesthetic identities not only of poets but also of publishers, the poets' socialisation spaces. This leads us to explore literary history, including the history of contemporary poetry since 1945 , and more broadly that of poetry as a whole, since poetry can only be understood in its historical perspective (Bourdieu, 1996). Here, the 
sources are manifold. Literary historians have published many analyses of the contemporary poetry field, its aesthetic issues and its history (e.g. Jarrety, 2001; Bancquart, 1996; Martin, 2013; Forest, 1995). Poets have also written widely about their sphere. A number of them have published memoires, intellectual autobiographies (e.g. Veinstein, 2016; Réda, 1995), or their letters. The editors themselves, many of whom are writers, have left autobiographies or letters (e.g. Paulhan and Gallimard, 2011; Cayrol, 1982; Boulanger, 1998). These sources reveal not only the literary history of poetry, but also its social history, through the composition of influential groups, poetry reviews and collections. We therefore studied numerous secondary sources that reported significant events in the history of contemporary poetry. Finally, we conducted 20 interviews with contemporary poetry actors.

\section{Publishers as aesthetic markers}

\section{A. The aesthetic identity of the publisher}

The range of aesthetic choices within French contemporary poetry was completely redefined after the Second World War. Doubtless, this redefinition took place by taking up once more the tension developed in nineteenth century poetry between meaning and form, between subjective expression and existence in the world, and research into formalism. Nevertheless, in the immediate post-war period, two related trends led to a profound renewal of French poetry. First, the war challenged the dominant aesthetic values in poetry, and in particular surrealism, which Breton, the leader of the movement, was unable to relaunch (Nadeau, 1970). At the same time, publishers were looking for new authors to revitalize their catalogues in these new circumstances (Simonin, 1998). Leading literary publishers competed to attract the best young writers and launched collections specifically for promising newcomers (Forest, 1995). This reorganisation was led by the three publishers who dominate French poetry: Gallimard, le Seuil and Flammarion. We will therefore explore the aesthetic identities of these three publishers, who work with all the best-known French poets.

Originally, Gallimard was an extension of the literary magazine Nouvelle Revue Française $(N R F)$ launched in 1908, under the aegis of André Gide in particular. Its aim at the time was to renew classical literature by promoting "pure" work, which rejects formalism and the idea that nothing but the text exists, promoting a certain formal continuity. This editorial line remained fairly vague, but kept Gallimard apart from the avant-garde, with the exception of surrealism, which can be seen as an extension of romanticism into the questions of the subject and lyricism (Nadeau, 1970). This policy continued after the war, and Gallimard did not publish the most 
radical avant-garde poetry, remaining oriented towards formalism. Indeed, for a long time Jacques Réda, a major contemporary poet and member of the dominant cluster, directed the $N R F$ and was at the same time a member of the firm's reviewing committee. He was an author "at the head of a revival of so-called neo-lyrical poetry, said to be a reaction to the deconstructed modernist landscape" (Jarrety, 2001: 654) working notably in regular verse (Réda, 1999). The critics recognise in Réda "a voice [that] attempts [...] to remain apart, a lyrical voice indeed, if lyricism is the expression of an existential wager" (Micolet, 2001: 655) and in Gallimard "a powerful narrative revival, relieved of theoretical weight: intimate, biographical writing about childhood, memorial literature, minimalist snippets from ordinary life, a new lyricism" (Cerisier, 2009: 517).

Just as Gallimard relied on the $N R F$ as a breeding ground, the group of poets published by le Seuil originated in a single literary magazine, Tel Quel. Around Tel Quel grew up, not a poetry movement, but more broadly an avant-garde movement for literature (novels, narratives, and poetry), politics and social sciences. Apart from the magazine, it has its own le Seuil collection. Its aim is to bring literature closer to the social sciences, and above all linguistics (Jakobson and Greimas in particular). In literature, this research results in a type of "textualisme" affirming that nothing exists in the text apart from the text; literature must not and cannot aim at representing the world, in what would necessarily be an illusion. Going further than the Nouveau Roman, which Tel Quel supported at its outset, it wants all meaning to be contained in the text: the meaning cannot pre-exists to the text nor be found beyond it. This is also a political wish, since literary text operates as a criticism of the usual language identified with the dominant ideology. "Writing is the continuation of politics by other means" (Tel Quel, 1968: 78). One of the major poets in this movement, Denis Roche, published "Le mécrit" (1972) and made his celebrated expression "poetry is inadmissible" the title of his complete poetry works (1995): classical form and lyricism are both theoretically wrong and ideologically complicit with the bourgeoisie.

The third aesthetic grouping in contemporary French poetry has also centred on a magazine and a publisher, the literary magazine Action Poétique $(A P)$ and Flammarion. Although the magazine does not belong to Flammarion, this firm has published many of the major contributors to AP, and the director of Poésie Flammarion since 1994, Yves Di Manno, has worked actively with AP. This group brings together a variety of authors concerned with the importance of form. "AP poets consider themselves custodians, historians and actors of the formal tradition" (Boulanger, 1998: 92). The formalism of Flammarion poets leads them, as 
Claude Adelen, one of the pillars of both AP and Flammarion, stresses, to "refuse any internal monologue" against lyrical poetry (cited in Boulanger, 1998: 96). Their ideas are closely akin to those of a number of American modernist poets (Pound, William Carlos Williams, Zukofski, Oppen, Ashbery). Without identifying with the textualism of Tel Quel, this trend favours formal work, as Yves Di Manno clearly states:

"Of course, I still feel closer to "formalists" (with the traditional speech marks) than to the others, because at least I learn a certain number of things when reading them. I'm thinking particularly about everything that has been accomplished around Action Poétique, about the circle created by Henri Deluy, with Jacques Roubaud, Paul Louis Rossi [...] The recent anthology by Pascal Boulanger is sufficient proof of this, it seems to me [...] To come back to the present, while I remains sceptical with regard to certain actions - but I have differing passions and do not belong to any clan - several books have moved me in recent years by the way they link this subversive work, which, as I see it, is the basis of modern writing, with consideration for formal discipline, which is without doubt the major advance of recent decades" (Di Manno, 1998).

Clearly, the aesthetic choices upheld by le Seuil and Flammarion are closer to each other than to those of Gallimard. Yet whilst authors do move between publishers, this movement is much more frequent between the two major publishers in the French literary field (Gallimard and le Seuil) than between those whose aesthetic choices ostensibly appear less in opposition. Within our sample, those authors who have published with Gallimard, whilst not being totally absent from Flammarion collections are underrepresented by this publisher (and the opposite is also true: authors who have published with Flammarion have published much less with Gallimard than the rest of our sample). However, authors who have published with le Seuil (or Gallimard) are more likely to have published with Gallimard (or le Seuil) than the other poets in our sample (c.f. table 1). Whilst aesthetic logics are not absent, as we see, they are overlaid and sometimes contradicted by logics of status.

Table 1 - The major publishers

\begin{tabular}{|c|c|c|c|c|}
\hline & & \multicolumn{3}{|c|}{ The authors who have published at least one book at... } \\
\hline & & Gallimard & Seuil & Flammarion \\
\hline ...have also & Gallimard & - & $57.1 * *$ & $22.9^{*}$ \\
\hline $\begin{array}{l}\text { published at } \\
\text { least one book }\end{array}$ & Seuil & $22.2 * *$ & - & 12.5 \\
\hline with ... & Flammarion & $16.7 *$ & 21.4 & - \\
\hline
\end{tabular}

Analysis: $22.2 \%$ of authors who have published at least one book at Gallimard have also published at least one book at le Seuil. This proportion is significantly higher (**) than for those who have never published with Gallimard. $16.7 \%$ of authors who have published at Gallimard have also published at Flammarion. This proportion is significantly lower (*) than for those who have never published at Gallimard . 
Similarly, publishers that organise and promote aesthetic choices operate more as poles of attraction than as exclusive strongholds. More modest houses gravitate around these major publishers, preferring to work with poets whose aesthetic tastes are, if not identical, at least compatible with those found at Gallimard, le Seuil or Flammarion. Thus (c.f. table 2), more than $40 \%$ of the authors who have published with Gallimard have also worked with A.L. Benoit, and $20 \%$ of those who have published with Flammarion have worked with Orange Export Ltd, a small house led by Hocquard, an important poet who strongly criticized lyricism and has never been published at Gallimard. Without being impermeable, these aesthetic groups are relatively independent of each other: Flammarion's authors are underrepresented in work published by firms in Gallimard's aesthetic orbit.

Table 2 - Major and other publishers

\begin{tabular}{|c|c|c|c|c|}
\hline & & Gallimard & Seuil & Flammarion \\
\hline \multirow{6}{*}{$\begin{array}{c}\text { Cluster } \\
\text { Gallimard }\end{array}$} & A. L. Benoit & $40.3 * *$ & 14.3 & $10.4^{*}$ \\
\hline & Mallessard & $26.4 * *$ & 7.1 & $2.1^{*}$ \\
\hline & Albin Michel & $37.5 * *$ & 32.1 & $6.2 *$ \\
\hline & Champ & & & \\
\hline & Vallon & $13.9 * *$ & 7.1 & $2.1^{*}$ \\
\hline & $\begin{array}{l}\text { Le Temps } \\
\text { qu'il fait }\end{array}$ & $25 * *$ & 17.9 & 10.4 \\
\hline \multirow{2}{*}{$\begin{array}{l}\text { Cluster } \\
\text { Seuil }\end{array}$} & A travers & 15.3 & $21.4 * *$ & 12.5 \\
\hline & Aencrages & 6.9 & $25 * *$ & 10.4 \\
\hline \multirow{4}{*}{$\begin{array}{c}\text { Cluster } \\
\text { Flammario } \\
\text { n }\end{array}$} & Apogée & 11.1 & 7.1 & $29.2 * *$ \\
\hline & Unes & $2.8^{*}$ & 10.7 & $14.6 * *$ \\
\hline & Orange & & & \\
\hline & Export Ltd & 13.9 & 21.4 & $20.8 * *$ \\
\hline
\end{tabular}

Analysis: $40.3 \%$ of authors who have published at least one book at Gallimard have also published at least one book at A.L. Benoit. This proportion is significantly higher (**) than for those who have never published at Gallimard. $10.4 \%$ of authors who have published with Flammarion have also published with A.L. Benoit. This proportion is significantly lower $(*)$ than for those who have never published at Flammarion.

French contemporary poetry is thus organised in separate aesthetic groups, which have long been clearly defined and are constantly joined by new poets. These aesthetic orientations are clustered around major publishers who organise their own constellations of smaller publishers with comparable (or at least compatible) aesthetic orientations. Indeed, publishers signpost the aesthetic choices of the world of contemporary poetry so clearly because they are established as mechanisms used to organise the field and to transmit a number of aesthetic conventions.

\section{B. Aesthetic families organised around publishers}


The reason that publishers are aesthetic markers is that they have gathered over several decades a group of poets sharing aesthetic tastes. However, it is also because these aesthetic affinities are developed and shared socially and in solidarity networks that help to organise the world of contemporary poetry around the publishers. Three mechanisms are central in this regard: the publishers select the texts; they are at the heart of the poets' socialization; and they develop poles in their relations of sociability.

The first of these mechanisms is to some extent the most expected, since it corresponds to a publisher's traditional function: that of sorting the texts sent to them into the work they wish to publish, and that which they reject. In poetry, this selection is generally undertaken by poets themselves who, of course, share the aesthetic tastes of the publisher. Thus, the Gallimard paperback poetry collection is today directed by André Velter, a poet influenced by Rimbaud, whose poetry is "patent, radically other, devoted to the sovereign energies of life, light, and love; confronting and disqualifying the disenchanted part of the world...” (Velter and Bianu, 2013). The traditional Gallimard editorial line is perpetuated here, as recognised - sometimes criticised - by more avant-garde authors. Take, as an example, this interview with a poet and publisher:

"The Gallimard poetry collection, which is the leading vector for promoting poetry in France, has an image of contemporary poetry that is, I would say, limited to a certain school, a certain tendency, when you see that there are three Grand Prix National de Poésie award winners it does not publish [Heidsieck, Fourcade, Tortel]. It is almost unjust towards... apart from Bernard Heidsieck ${ }^{1}$ they are not great revolutionaries. Fourcade is in the wake of Char, and Tortel neither is a great revolutionary. One asks himself why [they $\mathrm{d}$ not appear in the Gallimard pocket collection]. Once again, we get into..., into..." (interview of 20 September 2004).

However, the tendency for publishers to structure the aesthetic identities of the world of poetry is based on other mechanisms beyond the function of selection that is, of course, theirs. They constitute spaces that socialise newcomers to their world. This socialisation is first intellectual. Aspiring poets become familiar with the poetry of their seniors before proposing their own texts, and this encounter takes place in a space marked out by strong, stable editorial identities. Philippe Jaccottet, a major Gallimard author, has stood up for poets often published by the house throughout his career. In his collection of essays on contemporary poetry (2015) 89\% of the authors studied have published with Gallimard or Mercure (a subsidiary of Gallimard),

\footnotetext{
${ }^{1}$ The founder of sound poetry, one of the great avant-garde $20^{\text {th }}$ century poetry movements, which moved poetry away from the text and towards the stage
} 
10,7\% with le Seuil and 7,1\% with Flammarion; the Flammarion and Seuil authors have all published with Gallimard as well.

This literary socialisation is carried on by their entry into more concrete relationships in a space that is soon organised around the publisher. The trajectory of the young poetry collective that was brought together early on by the writer and editor Philippe Sollers, and which became Tel Quel, is a good example of this phenomenon. Tel Quel originated in a group of friends: many of its founders were colleagues in classes préparatoires or business schools, who met at the bar $d u$ Pont-Royal, where Sollers and his colleagues met later the future members Jean-Pierre Faye and Jean-Edern Hallier at the end of the 1950s. Several future principal Tel Quel poets (Pleynet and Roche in particular) met before the magazine was founded and were introduced to the new group through the intermediary of Jean Cayrol, a poet and editor at le Seuil. Cayrol published the young Tel Quel authors in his collection Ecrire and welcomed the magazine as a chance to develop the loyalty of these promising young authors.

The foundation of Tel Quel is moreover a typical example of the socialization organized around publishers in that it makes use of a senior tutelary figure, in this case Francis Ponge. Even if later on he achieved recognition as a novelist, it was under the protection of a poet that Sollers launched his career as a writer. Sollers sent Ponge a prose text inspired directly by the senior writer. Ponge attempted unsuccessfully to have the work published by Gallimard, after which Sollers turned to le Seuil. The partnership between Tel Quel and Ponge was thus forged around le Seuil and a network of friends: "the alliance between Ponge and what was to become the Tel Quel group might never have happened, of course. For it to occur, a series of chance meetings and reciprocal empathies was crucial. We can clearly see, though, how the convergence fully satisfies dual, symmetrical expectations: when he reaches his sixties, a poet is looking for followers who will guarantee the future of his work whilst, from their viewpoint, young people are looking for a mentor who will consecrate them as writers. The story of the alliance was also one of friendship" (Forest, 1995: 25).

The socialization that is built around publishers is replaced later on by the renewal of these friendships established by assiduously frequenting close circles in which aesthetic tastes are forged and cohesion develops. A number of the poets published by Gallimard were grouped over many years around Georges Lambrichs who, in 1967, founded the Cahiers $d u$ chemin, a magazine published by Gallimard, before taking charge of the publisher's flagship magazine, $N R F$. One of these poets, Jude Stéfan, described the weekly meetings of the leading Gallimard 
poets, headed by Lambrichs: "I could talk for hours about the magazine [Cahiers du chemin], which was published between 1967 and 1977. For example, about the people I met. At first, the "Cahiers du chemin" meals took place in the rue des Canettes [...] everyone knew each other. Lambrichs invited three or four people each time, and that's how I got to know them [...] Then, Lambrichs widened the circle, and invited people to his home in the rue de Villersexel. We sat around a big table, with him and his wife Gilberte at each end. The guests changed every week, but some people came very regularly, including me, because that way I escaped from the provinces. The kernel was made up of Janvier, Réda, Deguy - who came and went as he wanted - Trassard, and Chaillou" (Stéfan, 2005: 63-64). All of these poets (Deguy, Stéfan, Janvier, Réda - Trassard and Chaillou being novelists) have appeared in the Gallimard pocket collection.

The same type of sociable relations, organized around a senior figure (Henri Deluy), can be found with Flammarion poets. Deluy is indeed the poet who is most regularly in the Flammarion poetry collection. One of the poets in the group speaks ironically but with affection of the monthly meetings with the "Sultan": "We love our sultan passionately. We love him for the infinite gentleness of his blue eyes. Of course, he has his character; but we have ours, as well. He is not a tyrant, in any case. Every new moon, the Grand Council meets; everyone speaks. Some say that the sultan listening to us is at heart only the emanation of the collective will. Such a view is just and false. For there is a very good chance that in the absence of our sultan, the Empire would fall to pieces. Indeed, nobody would dream of usurping his role" (Petit, 1979).

Publishers are thus at the heart of the aesthetic segmentation of the poetry world. By accumulating in their catalogue poets who share certain aesthetic tastes, they progressively build a literary identity that distinguishes them from each other. This aesthetic identity, guaranteed by the poets who select texts for publication, acting as gatekeepers, is strengthened by the socialization and sociability processes that are also centered on the publishers. But how does this aesthetic segmentation of the poetry world apply vertically in the stable, shared hierarchies of consecration?

\section{Publishers at the heart of poetic consecration}

The aesthetic identities developed by publishers influence a poet's chances of consecration directly. We can see this clearly in table 3: Gallimard poets are overrepresented among the most recognized poets, whilst those with Flammarion are underrepresented. Indeed, Gallimard is the 
French publisher most able to establish writers (Simonin, 1998). Correspondingly, Flammarion poets are overrepresented among the least consecrated poets, while those who have published with Gallimard are underrepresented in this group. Poets who have published with le Seuil are distributed more evenly among the different levels of consecration. Certainly, poets who have published with le Seuil are overrepresented (underrepresented) in the dominant group of poets (the dominated group), which if we only look at those who have published with le Seuil but have not published with Gallimard, these anomalies disappear.

\section{Consecration of poets by publisher}

\begin{tabular}{lccc}
\hline & Dominant & Median & Dominated \\
\hline Gallimard & $76.7^{* *}$ & 49.3 & $24.4^{*}$ \\
Of whom Gallimard & & & $20^{*}$ \\
alone & $53.3^{* *}$ & 17.3 & 11.1 \\
\hline Seuil & $33.3^{* *}$ & 26.7 & 6,7 \\
Of whom Seuil alone & 10 & 40 & 4.4 \\
\hline Gallimard and Seuil & $23.3^{* *}$ & 8 & $51.1^{* *}$ \\
\hline Flammarion & $16.7^{*}$ & 9.3 & prod \\
\hline
\end{tabular}

The categorization of poets as dominant, median or dominated is based on the hierarchy we presented and discussed in Dubois and François (2013) - c.f. section II, Data \& Methods.

Analysis: 53.3\% of the dominant poets have published at Gallimard but not at le Seuil. This proportion is significantly higher $(* *)$ than for those who have never published at Gallimard, of at Gallimard and with Le Seuil. $24.4 \%$ of the dominated poets have published at Gallimard, some of whom have also published with le Seuil. This proportion is significantly lower $(*)$ than for those who have never published at Gallimard.

The consecration of poets is thus directly linked to their aesthetic position in the contemporary poetry world. How can we explain the fact that Gallimard poets are so overrepresented among the most consecrated poets, whilst Flammarion poets are so overrepresented in the least recognized group? We propose here two mechanisms, diffuse but significant, that may lead to such a clear link between publisher and degree of consecration.

The first of these is the role publishers play in the assessments of bodies that recognize poets and lead to their consecration: publishers function as a guarantee of quality; this alone is not enough on which to make an assessment, but it contributes (Karpik and Scott, 2010). The degrees of consecration that we have revealed are based on a comparison of the rankings drawn up by different groups: literary awards, academic work, critical acclaim, etc. These different groups give publishers a determining role, particular when awards juries are not contemporary poetry specialists. Thus, $90 \%$ of the poets in our population who have received the Prix 
Goncourt for poetry prize have published with Gallimard ${ }^{2}$. Similarly, $80 \%$ of the poets in our population who have received the Académie Française prize are Gallimard poets, and less than $10 \%$ are Flammarion poets. Both of these prizes are awarded by non-specialists, who certainly follow the most visible contemporary poetry publications, but who are not necessarily aware of the finer subdivisions or most recent alignments. They are also more receptive to more classical poetics, which are closer to their own aesthetic tastes; more experimental positions remain confined to the world of poetry. In other words, these bodies are at the heart of the management of the passage from recognition to renown (Lang and Lang, 1988). Among the different clues that contribute to the construction of the juries' assessment, publishers play a key role: they are a guarantee of quality and aesthetic orientation that can be used to make at least an initial selection among the competitors.

The role publishers play when assessments are made can be witnessed in another area of the consecration process, university. Many more Gallimard and Seuil poets than any others have been the subject of a thesis (57\% of Gallimard poets, $64 \%$ of le Seuil poets), whilst the proportion of Flammarion poets who have been the subject of a thesis does not differ significantly from the rest of our population. This is particularly true when the thesis directors are not contemporary poetry specialists: if we consider situations where the director has worked on only one contemporary poetry thesis, $77 \%$ of these theses deal with at least one Gallimard author, and $22 \%$ cover a Flammarion author. Even fewer theses are devoted to the study of poets who have published with le Seuil, but not with Gallimard (15\%).

The study of academic bodies that consecrate poets also reveals a second mechanism at work, resulting from the fact that poets are often intimately linked to the bodies that consecrate them: the solidarity and fault lines that prevail in consecration bodies carry over, at least partly, and doubtless to a lesser degree, those that prevail at publishers. Professors who have directed at least ten theses devoted to contemporary poetry are very often linked to publishers, either because they are poets themselves (such as Maulpoix, Collot, Conort and Gleize), or because they are assiduous, intimate fellow travelers, such as Jean-Claude Mathieu, one of the great university specialists in contemporary poetry: both because of his competence and because of their close association, the major twentieth century French poet, René Char, chose him to edit his complete works for Gallimard. Mathieu was also personally associated with Du Bouchet and Jaccottet, other major authors in the Gallimard nebula. In other words, the fault lines and

\footnotetext{
${ }^{2}$ Here, as in the rest of the text, the proportions that we cite are significant at the $5 \%$ level (Chi- 2 test).
} 
groupings of contemporary poetry can be found within the bodies that make a poet's reputation. It would be too simplistic, of course, to suppose that poets with certain aesthetic tastes, such as Jean-Marie Gleize, who is a formalist poet and a central member of the le Seuil group, only direct theses that study formalist poets: whilst theses directed by J.-M. Gleize study more Flammarion poets than those directed by most of his colleagues (with the exception of $\mathrm{M}$. Collot, who is, moreover, close to Gallimard), Gleize has also directed theses on Gallimard poets, and among many theses studying Gallimard poets along with Flammarion ones. Nonetheless, more of the thesis directors specializing in contemporary poetry are associated with Gallimard than with le Seuil or Flammarion. Whilst they are not exclusive, sectarian apologists for a single publisher's authors, understandably they are more inclined to direct theses on subjects that they know and appreciate.

The mechanism that carries aesthetic and editorial divisions over to consecrating bodies also occurs with literary awards. It is often pointed out with regard to prizes for new novels that dominant publishers strongly influence jury selection, since members who are also writers are often linked to these publishers: Gallimard, Le Seuil and Grasset (which does not publish poetry) clearly dominate the prizewinners (Ducas, 2013). Even if the financial stakes cannot be compared, the world of poetry is also influenced by this type of logic: more than $80 \%$ of the authors in our population who have received the Prix Mallarmé have published with Gallimard. Among the current members of the Académie Mallarmé, 36\% have published at least one book with Gallimard or Mercure, 3\% with le Seuil and 6\% with Flammarion. The prize is dominated by more traditional, lyrical forms of poetry; no more radically experimental poet has won the prize, only neo-surrealists, poets close to the everyday lyricism of Réda, or even religious poets. Whilst it is doubtless exaggerating to propose that a given consecrating body is in the hands of a given publisher, the partial overlap between consecrating bodies and publishers (or between the social space of production and that of consumption) explains the fact that the fault lines that we find in one area are also found, to a lesser degree, in another.

\section{Conclusion}

Status theory proposes an analytical frame that can explain the spectacular differences in degree of consecration that appear retrospectively between certain artists. However, it can be accused, as the social sciences often are when they attempt to analyze the arts world, of ignoring the aesthetic dimension of the works produced. In other words, it passes over what makes this world distinct from other fields of production. In this article we have attempted to demonstrate how it 
is not only possible but also necessary to take into account aesthetic segmentation in the arts world if we are to explain the hierarchies that occur there. In poetry, poets' aesthetic choices at the beginning of their career are often crucially important for their future level of consecration.

The analysis of aesthetic tastes does not simply add a parameter to the model; it also enhances understanding of the sociological significance of the variables used. In "standard" status theory, as presented, for example, by Menger (2014), selective matching refers to the comparison of two statuses. It postulates that the actor is rational (i.e. wishes to optimize his/her position in the game of comparisons) and knowledgeable (i.e. aware of the relative positions of his potential partners). The inclusion within status theory of aesthetic affinity clarifies, completes and frames the nature of these relations. It explains in detail why a given poet will choose a given publisher, rather than another of equivalent status, and the "space of possibilities" (Bourdieu, 1996) that it opens for him: a formalist stands very little chance of being published by Gallimard. Poetical engagement, which is based above all on aesthetic reasons, will lead a given aspiring formalist poet to read and then associate with other formalist poets, publishers and critics. The issue is not that individuals reach a ceiling because of sub-optimal matching; it is that groups form based on aesthetic affinity, and their unequal success, today, in consecrating bodies mitigates (or, on the contrary, multiplies) the chances of future consecration of those who are starting today and will be judged tomorrow.

\section{References}

Bancquart M-C. (1996) La poésie française du surréalisme à nos jours, Paris: Ellipses.

Becker HS. (1984) Art worlds, Berkeley: University of California press.

Boulanger P. (1998) Une "Action poétique" : de 1950 à aujourd'hui : l'anthologie, précédée d'une présentation historique, [Paris]: Flammarion.

Bourdieu P. (1996) The Rules of Art: Genesis and Structure of the Literary Field: Stanford University Press.

Cayrol J. (1982) Il était une fois Jean Cayrol, Paris: Seuil.

Cerisier A. (2009) Une histoire de la NRF, Paris: Gallimard.

Di Manno Y. (1998) La poésie contemporaine en questions. Entretien avec Lionel Destremeau. Prétexte.

Dubois S and François P. (2013) Career paths and hierarchies in the pure pole of the literary field: The case of contemporary poetry. Poetics 41(5): 501-523.

Ducas S. (2013) La littérature à quel (s) prix?: Histoire des prix littéraires: La Découverte.

Forest P. (1995) Histoire de Tel Quel, Paris: Seuil.

Giuffre K. (1999) Sandpiles of Opportunity: Success in the Art World. Social Forces 77(3): 815-832.

Jaccottet P. (2015) L'entretien des Muses, Paris: Gallimard.

Jarrety M. (2001) Dictionnaire de poésie : de Baudelaire à nos jours, Paris: Presses universitaires de France.

Karpik L and Scott N. (2010) Valuing the unique: The economics of singularities: Princeton University Press Princeton.

Lang GE and Lang K. (1988) Recognition and Renown: The Survival of Artistic Reputation. The American Journal of Sociology 94(1): 79-109. 
Martin S. (2013) Les Cahiers du Chemins (1967-1977). Poétique d'une revue littéraire, Paris: Honoré Champion.

Mary P. (2006) La Nouvelle Vague et le cinéma d'auteur. Socio-analyse d'une révolution artistique, Paris: Seuil.

Menger P-M. (2014) The economics of creativity, Cambridge, MA: Harvard University Press.

Micolet H. (2001) Jacques Réda. In: Jarrety M (ed) Dictionnaire de poésie. Paris: PUF, 654-659.

Mollier J-Y. (1988) L'argent et les lettres : histoire du capitalisme d'édition : 1880-1920, [Paris]: Fayard.

Nadeau M. (1970) Histoire du surréalisme, Paris: Seuil.

Paulhan J and Gallimard G. (2011) Correspondance (19119-1968), Paris: Gallimard.

Petit M. (1979) Nous aimons. Action Poétique 79.

Podolny JM. (1993) A Status-Based Model of Market Competition. American journal of sociology 98(4): 829-872.

Réda J. (1995) La Sauvette, Lagrasse: Verdier.

Réda J. (1999) Celle qui vient à pas légers, Saint-Clément-la-Rivière: Fata Morgana.

Roche D. (1972) Le mécrit : poèmes ; précédé de Lutte et rature, Paris: Le Seuil.

Roche D. (1995) La poésie est inadmissible, Paris: Seuil.

Schmutz V. (2005) Retrospective Cultural Consecration in Popular Music Rolling Stone's Greatest Albums of All Time. American behavioral scientist 48(11): 1510-1523.

Shin D, Lee K and Lee H. (2014) Neoliberal marketization of art worlds and status multiplexity: Price formation in a Korean art auction, 1998-2007. Poetics 43: 120-148.

Simonin A. (1998) L'édition littéraire. In: Fouché P (ed) L'édition depuis 1945. Paris: Cercle de la Librairie, 30-87.

Stéfan J. (2005) Rencontre avec Tristan Hordé, Paris: Argol.

Tel Quel. (1968) Théorie d'ensemble, Paris: Seuil.

Veinstein A. (2016) Les Ravisseurs, Paris: Grasset.

Velter A and Bianu Z. (2013) Prendre feu, Paris: Gallimard. 